\title{
The Design of a Land Suitability Model on Rice Production Estimation using Remote Sensing Method in Merauke District Papua
}

\author{
Heru Ismanto, Abner Doloksaribu, Diana Sri Susanti
}

\begin{abstract}
The area of agricultural land in Merauke Regency according to data from Bappeda (Agency for Regional Development) of Merauke Regency is for about 4.6 million hectares in 2015 and within the next 5 years will be cultivated as much as 1.2 hectares, especially for rice field and secondary crops plants [1].This study has purpose to estimate the value of rice production by using dry-milled rice with a land suitability approach using decision tree analysis and remote sensing methods in Merauke Regency. Remote sensing that has been corrected geometrically and radio-metrically is analyzed by using decision tree analysis to derive information on paddy/rice and non-rice field land use and which is reclassified by using field unit information based on field observations which will result in accuracy of use and producer. The rice field data is then processed to derive information on the rotation pattern of rice by using a decision tree analysis that is using input data on land characteristics which will produce total accuracy. Information on rice field area and rotation patterns are complemented by land productivity (tons / ha) sourced from BPS (Central Statistics Agency) data and interviews with land cultivators and local residents (farmers) were used to calculate the total rice production value on dry-milled rice The results of calculations by using this method are expected to have a fairly large surplus of calculations, both data from BPS (Central Bureau of Statistics) and data from interviews with land cultivators and local residents (farmers). Thus, these results are expected to show that the land suitability approach by using remote sensing methods for estimating rice production can be used to produce information on rice field area and rotation patterns with moderate to high accuracy.

Keywords-Rice production, land suitability, decision tree, remote sensing, Merauke Papua.
\end{abstract}

\section{INTRODUCTION}

$\mathbf{R}_{\text {ice is a food crop commodity that is important for food }}$ consumption for the majority of the population in Indonesia.

Revised Manuscript Received on October 20, 2020.

* Correspondence Author

Heru Ismanto*, 1Department of Informatics System, Faculty of Engineering, Universitas Musamus Merauke Papua Indonesia. Email: heru@unmus.ac.id

Abner Doloksaribu, 2Department of Civil Engineering, Faculty of Engineering, Universitas Musamus Merauke Papua Indonesia. Email: abner_doloksaribu@yahoo.com

Diana Sri Susanti, 3Department of Agroteknologi, Faculty of Agriculture, Universitas Musamus Merauke Papua Indonesia. Email: Diana@unmus.ac.id

(C) The Authors. Published by Blue Eyes Intelligence Engineering and Sciences Publication (BEIESP). This is an open access article under the CC BY-NC-ND license (http://creativecommons.org/licenses/by-nc-nd/4.0/)
According to BPS (Central Bureau of Statistics) data, Indonesian rice consumption in 2009 is the largest consumption in the world with $139 \mathrm{~kg}$ per capita each year or double greater from the average rice consumption of the world's population [2]. Rice also contributed an economic value of 262 trillion rupiah in 2011 as confirmed by the ministry of agriculture [3]. This number shows that rice plays an important role in supporting food security and economy in Indonesia. Therefore, it needs to be managed properly. Merauke Regency is the largest rice producer in Papua Province. In 2018, rice production in Merauke Regency was about 299,877.29 tons with the width of its rice field area is $57,263.50$ hectares. There was an increase in production from the previous year [1]. The potential production value in agriculture and plantations is important data that needs to be taken to regulate the application of fertilizers and other treatments so that it can increase profits and reduce aspects of environmental pollution due to chemicals used in processing [4]. In Indonesia, the production estimates for agricultural commodity yields are often not as expected as in 2010 where the data showed that a rice surplus of 5 million tons but in the field area, there was not enough rice [5]. Weather and climate change make it difficult to estimate agricultural production [5]. This is exacerbated by the method of calculating national production which still needs to be refined because it is often not in accordance with the reality on the field [6]. An accurate method of calculating national rice production needs to be developed to support food security in Indonesia in order to build a linkage between the amount of production, stock and the price of rice [5]. Remote sensing technology has been developed to derive data which is related to soil characteristics, plant characteristics and crop yield maps. Remote sensing uses a statistical-empirical approach and a physical approach to predict the biophysical and biochemical characteristics of vegetation [7]. Furthermore, it can be included as the empirical statistical approach uses a regression function of the measurement of biophysical and biochemical characteristics with spectral measurements in the form of vegetation indices. Regression statistical function are reliable techniques for solving short-term and long-term prediction problems, for example for cases such as prediction of crop yields, prediction of spread of infectious diseases [8], determine the regional prioritized areas [9], and prediction of tourist visits [10];[11]. This vegetation index is used to measure biophysical aspects of plants such as bush canopy [12], chlorophyll content and wheat LAI [13], biomass, Photosynthesis Radiation (PAR),
Active

and Sciences Publication

(C) Copyright: All rights reserved.

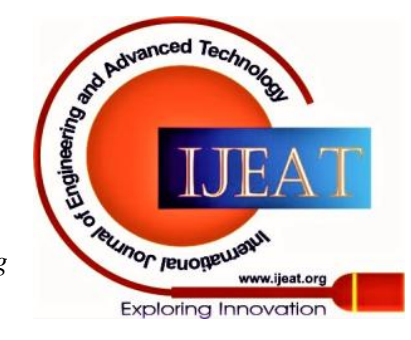




\section{The Design of a Land Suitability Model on Rice Production Estimation using Remote Sensing Method in Merauke District Papua}

LAI and penology in 4 food crops (wheat, maize, peanuts and canola). [14] and it also involved to the level of vegetation health [15]; [16]; [17]. Research on rice includes the modeling of rice growth stages [18], estimation of the biochemical and biophysical characteristics of rice [19] and prediction of variations in rice production [20].

This study uses remote sensing imagery, which is an image, and it is used for monitoring natural resources which is expected to be able to cover the study area well and map rice fields with a high enough spectral resolution consisting of 9 spectral channels. The research flow diagram can be seen in Figure 1.

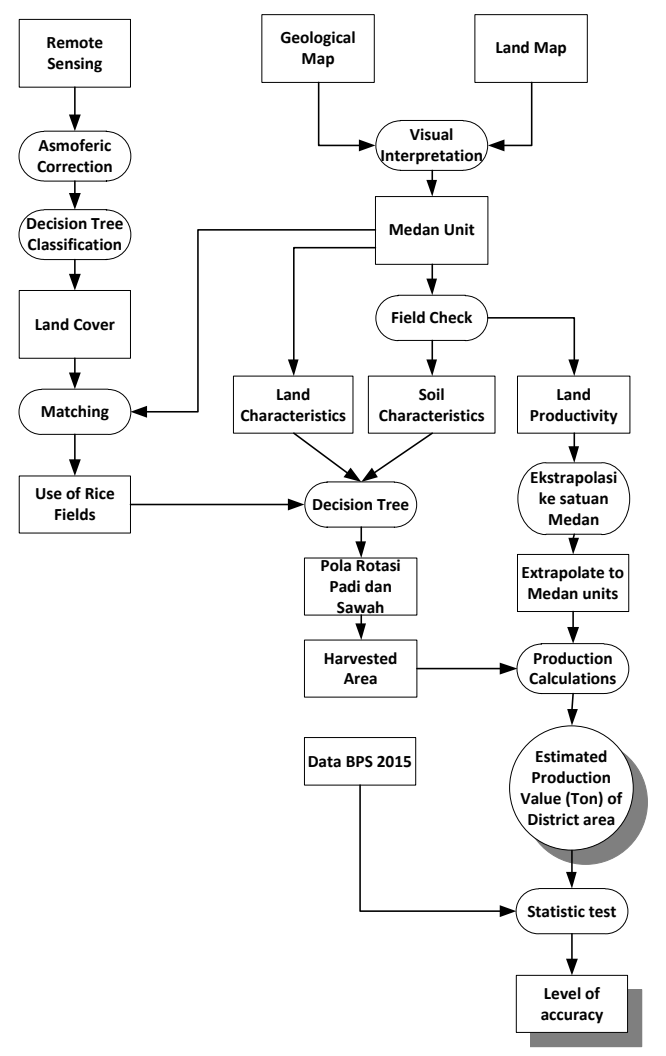

Figure 1. Research Flow Diagram

\section{RESEARCH METHOD}

The research method used in this study included into 3 stages, and they are such as data preparation, pre-field stage for data collection, and the post-field stage, it is the re-interpretation process to the final map making.

\section{A.Pre-field Stage}

This stage consists of pre-processing on image by using remote sensing as well as the classification of cover and land use. The pre-image processing stage is used in order to make the image can be used in the next process. Image pre-processing consists of 2 stages such as radiometric correction and geometric correction. Atmospheric correction is required when extracting bio-physical variables from the image, especially if 2 images with different dates are used to be compared. Atmospheric correction is also used when multi-temporal images are being processed by using linear equations and compared between dates. Therefore, if they are not corrected, the difference will be small and on the object's reflection or transformation result cannot be compared. The differences between land cover and land use is that the land cover is included vegetation and artificial features that cover the surface of the land, while the land use is all types of use on land by humans which include use for agriculture to sports fields, residential houses to restaurants, hospitals to cemeteries. The land cover information in this research is extracted by using a decision tree classification by using a training area with information on the spectral value of the image. The classification system used for land cover information is the third order spectral dimension classification system [21].

\section{B.The Field Stage}

The field stage consists of 2 main activities; they are such as field sampling and interviews with local residents. Samples taken in this field work are samples to test the accuracy of mapping for each variable and also soil samples to be brought to the laboratory. Sampling was carried out at each different stratum of land units. The interview process with local residents was also carried out mainly to obtain a range of rice production figures in Merauke District from 4 sample districts. Sampling of soil in the field was done quantitatively through laboratory tests through laboratory tests to measure parameters of clay, sand and dust levels as well as C-organic content, permeability, degree of acidity and levels of P2O5.

\section{C.Post-Field Stage}

At this stage, there will be some processes such as calculating the accuracy and re-interpretation, analysis of the decision tree, and also build a decision tree role and estimate rice production. The results of the field samples are used to calculate the accuracy of the parameters used in the study. Calculation of accuracy by using an error matrix can be seen in Figure 2. Field samples are also used to carry out the process of reinterpretation, or drawing new boundaries by referring to field data references and using them on remote sensing data. In addition, soil samples taken in the field are tested in the laboratory to obtain soil physical and chemical properties.

\begin{tabular}{|c|c|c|c|c|c|c|c|}
\hline \multicolumn{7}{|c|}{ Reference Data } & \multirow{8}{*}{$\begin{array}{l}\text { Land Cover Categories } \\
D=\text { deciduous } \\
C=\text { conifer } \\
A G=\text { agriculture } \\
S B=\text { shrub } \\
\text { OVERALL ACCURACY = } \\
\begin{array}{l}655+81+85+900 / 434= \\
321 / 434=74 \%\end{array}\end{array}$} \\
\hline \multirow{9}{*}{$\begin{array}{l}\text { Classified } \\
\text { Data }\end{array}$} & \multirow[b]{2}{*}{ D } & D & c & $\mathrm{AG}$ & $S B$ & $\begin{array}{l}\text { row } \\
\text { total } \\
\text { tol }\end{array}$ & \\
\hline & & 65 & 4 & 22 & 24 & 115 & \\
\hline & c & 6 & 81 & 5 & 8 & 100 & \\
\hline & $\mathrm{AG}$ & 0 & 11 & 85 & 19 & 115 & \\
\hline & $\mathrm{SB}$ & 4 & 7 & 3 & 90 & 104 & \\
\hline & \multirow[t]{4}{*}{$\begin{array}{l}\text { column } \\
\text { total }\end{array}$} & 75 & 103 & 115 & 141 & 434 & \\
\hline & & & & & & & \\
\hline & & \multicolumn{4}{|c|}{ PRODUCER'S ACCURACY } & \multicolumn{2}{|c|}{ USER'S ACCURACY } \\
\hline & & \multicolumn{3}{|c|}{$\begin{array}{l}D=65 / 75=87 \% \\
C=81 / 103=7796 \\
A G=85 / 115=74 \% \\
S B=90 / 141=64 \%\end{array}$} & & \multicolumn{2}{|c|}{$\begin{array}{l}D=65 / 115=87 \% \\
C=81100=81 \% \\
A G=85 / 115=74 \% \\
S B=90 / 104=87 \%\end{array}$} \\
\hline
\end{tabular}

\section{Figure 2. Calculation of error Matrix}

Meanwhile, decision tree analysis requires 3 components; they are such as hypotheses, rules and condition as input into knowledge engineer. The hypothesis is a domain that will be tested by using inductive logic and the level of trust to get logical conclusions. Rule is the core of decision tree analysis process because the rule provides specific conditions that will fulfill the hypothesis which is being made, and if the rule is not suitable then there will be inaccurate variables.

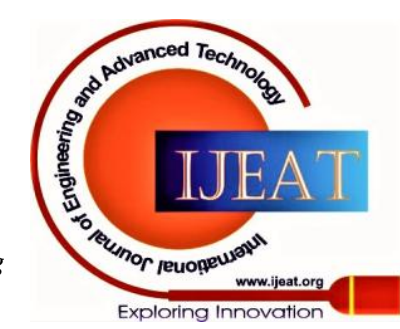


Condition is the result of a rule that describes the conditions for a hypothesis [22].

Decision tree in this study is used to map land cover and rotation patterns. The decision tree classification which is used is a tree classification with the induction method where rules are made based on the training area data that they have.

On land cover mapping, the spectral average value of each data channel from remote sensing is used as the basis for making trees. Meanwhile, on the rotation pattern, the land characteristics data in the form of soil survey data and visual interpretation results are used as sample data for use in decision tree analysis to map rice crop rotation patterns in parts of Merauke district. In this case, a link will be obtained between the land suitability criteria data and the rice crop rotation pattern used to calculate the annual rice production value in some parts of Merauke district.

Meanwhile, in the estimation of rice production, the information data on agricultural land use resulting from the decision tree analysis is derived into harvested area data. The harvested area obtained will be used to calculate the rice production by multiplying the agricultural productivity in Merauke Regency. In this study, it is assumed that the resulting classification of rice field area is the harvest area without considering the risk of crop failure.

The value of land productivity is obtained through interviews with local farmers and local residents, and then those are extrapolated to each field unit with the assumption that the amount of land productivity for areas with the same terrain unit will have the same land productivity as well. The value of land productivity will use units of tones / ha and in the amount of milled-dry rice, it will be adjusted to the comparative data from BPS (Central Bureau of Statistics). The conversion of land productivity values will be carried out if the weight indicated is not the weight of milled-dry rice because in the process from wet grain to milled dry grain (GKG), there are processes that can reduce the weight of rice, such as drying, storage and milling.

\section{DISCUSSION}

This research for calculating rice production in 2019 uses remote sensing technology to calculate the harvested area in four districts of Merauke Regency with a decision tree analysis which is also used to predict rice planting patterns as the basis for calculating the amount of rice production while land productivity data is obtained from interviews with land cultivators. and local residents as well as using land productivity data from BPS (Central Bureau of Statistics). The calculation of rice production uses 3 components, they are such as harvested area, rotation pattern and land productivity. Based on the results of the analysis of the process carried out, errors in the production calculations can be resulted from the limitations of the decision tree method and the limitations of remote sensing data. In other hand, the other things such as the accuracy of comparative data derived from BPS (Central Bureau of Statistics) data also need to pay attention to the calculation of the accuracy of this rice production calculation.

\section{A. The Calculation of Harvested Area}

The width of harvested area in this calculation is generated from the area of rice fields by using the decision tree classification which has gone through binary logic analysis with field units and is filtered for majorities with a $3 \mathrm{x}$ 3 filter. The other factor that takes part in accounting the number of rice production is the use of number in the width of rice field as the number of harvest with the assumption that all rice fields will produce rice in 2019. The difficulty in determining the amount of shrinkage of the harvested rice field becomes the basis for using the rice field area as the harvest area because it is influenced by many factors such as pests and irrigation conditions. Based on data from the agricultural department, pests can affect the amount of rice fields that can be harvested. In Merauke district, pests such as leafhoppers and rats have attacked the rice fields of villagers, which have resulted in a reduction in the area of harvestable fields. Therefore, it is necessary to develop a method to detect the size of the paddy field before harvesting to obtain the real value of the harvested area.

\section{B. Determination of the Rotation Pattern of Rice Planting}

The template is used to format your paper and style the text. All margins, column widths, line spaces, and text fonts are prescribed; please do not alter them. You may note peculiarities. For example, the head margin in this template measures proportionately more than is customary. This measurement and others are deliberate, using specifications that anticipate your paper as one part of the entire proceedings, and not as an independent document. Please do not revise any of the current designations.

\section{Land Productivity Determination}

Land productivity reflects to the amount of rice production each of unit area (ton / ha). This figure was generated from the results of field interviews. Productivity figures also use BPS data generated through measurements by using tile method and using rice field samples before harvest. This BPS (Central Bureau of Statistics) data uses district boundaries as a unit for analyzing the value of land productivity. The accuracy of land productivity values from interviews with farmers and local residents is difficult to determine because it is only an estimate so that the value of rice production by using this land productivity figure records the lowest accuracy than using BPS (Central Bureau of Statistics) land productivity figures.

The ideal conditions for measuring land productivity for rice can be obtained by measuring the productivity of the land right at the time and the rice fields are harvested by using the tile method as what is done by BPS (Central Bureau of Statistics) so that the value of the weight each area of the rice field is harvested. This condition is quite difficult to achieve due to differences in the planting and harvesting periods of rice so that sampling to measure the amount of land productivity right before the harvest period is often not achieved, including by BPS (Central Bureau of Statistics) because the fields which will be sampled have often been harvested before measurement.

\section{METHOD USE RECOMMENDATIONS}

The remote sensing method which is used in this study is decision tree analysis to map rice-fields and rice field rotation patterns by using land suitability parameters

Published By:

Blue Eyes Intelligence Engineering and Sciences Publication

(C) Copyright: All rights reserved.

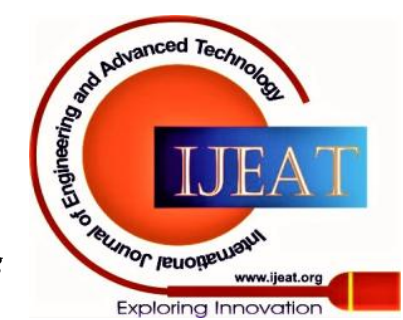




\section{The Design of a Land Suitability Model on Rice Production Estimation using Remote Sensing Method in Merauke District Papua}

such as area morphology, surface soil, surface water, surface drainage which is interpreted by using remote sensing and physical and chemical parameters of soil such as soil texture, degree of acidity, P2O5 content and C-organic content in the soil which is obtained from field measurements.

The results of the analysis by using remote sensing data with decision tree analysis are expected to be used properly to map the rice fields in Merauke district. The spectral analysis used as the basis for the decision tree analysis coupled with the analysis of the interpretation of land characteristics and strengthened by field observations is expected to be able to sharpen the decision tree analysis as evidenced by the increase in mapping accuracy and semantic accuracy of rice field mapping. The use of decision tree analysis method with land suitability parameters for mapping rotation patterns by using remote sensing is expected to record accuracy at the intermediate level. The number of factors that influence the pattern of rice crop rotation which is not included in the analysis such as climatic factors and those are such as rainfall and temperature are among the factors that can affect low accuracy. In addition, the accuracy value can also be generated from the lack of detail in the land form unit used for the rotation pattern mapping unit so that it fails to capture the variability of rice crop rotation patterns in Merauke Regency.

\section{CONCLUSSION}

The conclusion from this research are the ability of remote sensing methods in mapping land cover and land use, the role of field units in reclassifying the distribution of rice fields in determining harvested areas, the ability of decision tree analysis in determining the rotation pattern of rice plants based on land and soil characteristics data and integration of the three components of the calculation of rice production and those are such as harvested area, rotation pattern and land productivity to calculate rice production in 2019 in four districts of Merauke Regency.

\section{ACKNOWLEDGMENT}

The author would like to thank to the Ministry of Research and Technology / National Research and Innovation Agency of the Republic of Indonesia for assistance with research costs for the second Year 2020 Basic Research scheme so that the author can participate in international conference activities and produce international proceedings

\section{REFERENCES}

1. BPS Kabupaten Merauke (2019). Kabupaten Merauke Dalam Angka 2019. Kabupaten Merauke: Badan Pusat Statistik Kabupaten Merauke

2. Firmansyah, T. (2010). http://www.republika.co.id/berita/ breakingnews/nasional/ 11/01/13/ 158052

3. Octaviano, T. (2011). Nilai Ekonomi Beras Investor. Retrieved http://www.investor.co.id/

home/nilai-ekonomi-beras-capai-rp262triliun/21657

4. Ye, X., Sakai, K., Sasao, A., \& Asada, S.-i. (2008). Potential of airborne hyperspectral imagery to estimate fruit yield in citrus. Chemometrics and Intelligent Laboratory Systems, 90, 132-144. doi: 10.1016/j.chemolab.2007.09.002

5. Arifin, B. (2009). Tantangan baru ekonomi pangan. Economic Review, 1-9.

6. Prabowo, E. H., \& Suprihadi, M. (2011). Data Produksi Beras Bisa Dikoreksi, Kompas. http://bisniskeuangan.kompas.com/ read/2011/09/16/13055364/Data.Produksi.Beras.Bisa. Dikoreksi

7. Dorigo, W., Richter, R., Baret, F., Bamler, R., \& Wagner, W. (2009). Enhanced Automated Canopy Characterization from Hyperspectral

Data by a Novel Two Step Radiative Transfer Model Inversion Approach. Remote Sensing, 1, 11391170. doi:10.3390/rs1041139

8. Munir, A.Q., Hartati, S. and Musdholifah, A. (2019). Early Identification Model for Dengue Haemorrhagic Fever (DHF) Outbreak Areas Using Rule-Based Stratification Approach. International Journal of Intelligent Engineering and Systems (IJIES), Vol 12, No. 2, pp. 246-260.

9. Ismanto, H., Azhari, Suharto, Arsyad, L. (2018). Ranking Method in Group Decision Support to Determine the Regional Prioritized Areas and Leading Sectors using Garrett Score. International Journal of Advanced Computer Science and Applications (IJACSA), 9(8), pp.94-99.

10. Sugiartawan, P., Hartati, S. and Musdholifah, A., 2020. Modeling of a Tourism Group Decision Support System using Risk Analysis based Knowledge BaseNo Title. International Journal of Advanced Computer Science and Applications(IJACSA), 11(7), pp.354-363.

11. Sugiartawan, P. and Hartati, S., 2018. Group Decision Support System to Selection Tourism Object in Bali Using Analytic Hierarchy Process ( AHP ) and Copeland Score Model. In 2018 Third International Conference on Informatics and Computing (ICIC). Palembang, Indonesia: IEEE, pp. 1-6

12. Brantley, S. T., Zinnert, J. C., \& Young, D. R. (2011). Application of hyperspectral vegetation indices to detect variations in high leaf area index temperate shrub thicket canopies. Remote Sensing of Environment, 115, 514-523. doi: 10.1016/j.rse.2010.09.020

13. Xiaoping, W., \& Ni, G. (2008). Hyperspectral Reflectance And Their Relationships With Spring Wheat Growth Status Characteristics In Rained Agriculture Areas Of Loess Plateau. The International Archives of the Photogrammetry, Remote Sensing and Spatial Information Sciences, XXXVII.

14. Hatfield, J. L., \& Prueger, J. H. (2010). Value of Using Different Vegetative Indices to Quantify Agricultural Crop Characteristics at Different Growth Stages under Varying Management Practices. Remote Sensing, 2, 562-578. doi: 10.3390/rs2020562

15. Castro, K. L., \& Sanchez-azofeifa, G. A. (2008). Changes in Spectral Properties, Chlorophyll Content and Internal Mesophyll Structure of Senescing Populus balsamifera and Populus tremuloides Leaves. 51-69.

16. Eitel, J. U. H., Keefe, R. F., Long, D. S., Davis, A. S., \& Vierling, L. a. (2010). Active ground optical remote sensing for improved monitoring of seedling stress in nurseries. Sensors (Basel, Switzerland), 10, 2843-2850. doi: 10.3390/s100402843

17. Meroni, M., Rossini, M., Picchi, V., Panigada, C., Cogliati, S., Nali, C., \& Colombo, R. (2008). Assessing Steady-state Fluorescence and PRI from Hyperspectral Proximal Sensing as Early Indicators of Plant Stress: The Case of Ozone Exposure. Sensors, 8, 1740-1754.

18. Yang, C.-M., \& Chen, R.-K. (2004). Modeling Rice Growth with Hyperspectral Reflectance Data. Crop Science, 44, 1283. doi: 10.2135/cropsci2004.1283

19. Evri, M., Sadly, M., \& Kawamura, K. (2010). Diagnosing Ground-based Hyperspectral Red Edge Position Over Rice Canopy to Estimate Biophysical and Biochemical Parameters. Paper presented at the Pertemuan Ilmiah Tahunan MAPIN, Bogor.

20. Abbasi, M., Darvishsefat, A. A., \& Schaepman, M. E. (2010). Spectral Reflectance of Rice Canopy and Red Edge Position (REP) as Indicator of High-Yielding Variety. ISPRS TC VII Symposium, XXXVIII, 1-5.

21. Danoedoro, P., Phinn, S., \& Mcdonald, G. (2004). Developing A Versatile Land-Use Information System Based on Satellite Imagery for Local Planning in Indonesia Phase I : Establishment of Classification Scheme. Paper presented at the GISDECO 2004: 7th Seventh International on GIS in Developing Countries, Universiti Teknologi Malaysia, Skudai, Johor, Malaysia.

22. Jensen, J. R. (2005). Introductory Digital Image Processing (3rd ed.) Englewood Hills, NJ: Prentice Hall.

\section{AUTHORS PROFILE}

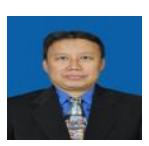

Heru Ismanto, received his Bachelor of Science, Master of Computer Science and Doctoral degrees from Padjadjaran University Bandung and Gadjah Mada University Yogyakarta Indonesia respectively in 1996, 2009 and 2019. Currently he is a lecturer in the Department of Informatics, Musamus University,

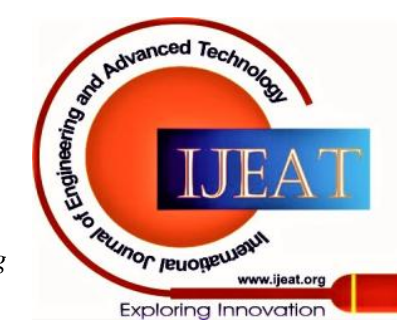


Merauke, Papua. The research area is in the Group Decision Support System, GIS, e-Government System. He can be contacted via email: heru@umus.ac.id

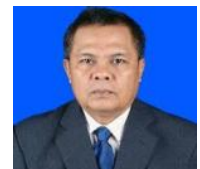

Abner Doloksaribu, received his bachelor's of Civil Engineering, and Master of Civil Engineering from Bandung State University and Hasanuddin University in 1982 and 2009 respectively. He was interesting in flooded System. He can be contacted by email: abner_doloksaribu@yahoo.com

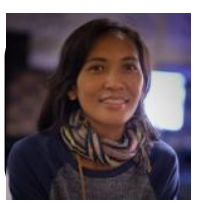

Diana Sri Susanti,, received bachelor's of holticulture from Universitas Of Papua Indonesia in 2008, received Master of holticulture from Hasanuddin University, Makassar, Indonesia in 2014. Currently, he is a lecturer at Department of Agroteknologi in Universitas Musamus, Merauke, Papua, she can be contacted by email: Diana@unmus.ac.id

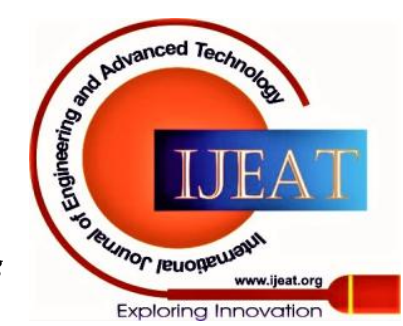

